Research Report

\title{
The Effect of Giving Okra (Abelmoschus Esculentus) Extract on the Increase of Vascular Endhothelial Growth Factor (VEGF)
}

\author{
Muhammad Luthfi, Wisnu Setyari Juliastuti and Nidya Pramesti Olifia Asyhari \\ Departement of Oral Biology, \\ Faculty of Dental Medicine, Universitas Airlangga \\ Surabaya - Indonesia
}

\begin{abstract}
Background: People with diabetes mellitus who perform tooth extraction related to the complications that disrupt the process wound healing. Diabetics have persistent inflammatory phase and abnormal angiogenesis in proliferation phase. Treatment for people with diabetes mellitus is done through increase VEGF. Herbal medicine that use extracts from plants have benefits in wound healing processes such as okra fruit extract because it contains flavonoids. Flavonoids in accelerating wound healing in patients diabetes mellitus can through its role as anti-diabetic, anti-inflammatory and antioxidant. This plays a role in the persistent inflammatory resolution process leading to proliferation by macrophages and immunomodulatory effects of macrophage function in issuing growth factors. Purpose: To prove okra fruit extract (Abelmoschus esculentus) influences the increase in VEGF expression in the process of healing wounds from tooth extraction of diabetes mellitus Wistar rats. Methods: Laboratory experimental research with randomized post-test only. The control group used 24 Wistar mice which were divided into two groups namely the control group (STZ induction) and the treatment group (STZ induction by giving okra fruit extract). Tooth extraction is done on the incisors left lower jaw. 4 mice from each group were sacrificed on day 3, 5 and 7 after revocation. A Socket is cut for inspection immunohistochemistry. Results: VEGF expression of the control group compared to the group the treatment showed significant results ( $p<0.05)$. Conclusion: Administration of extracts okra (Abelmoschus esculentus) has the effect of increasing expression VEGF in the healing process of wistar tooth extraction wounds with diabetes mellitus.
\end{abstract}

Keywords: diabetes mellitus; Okra fruit extract; VEGF; wound healing

Correspondence: Muhammad Luthfi, Departement of Oral Biology, Faculty of Dental Medicine, Universitas Airlangga, Jl. Prof. Dr. Moestopo No. 47 Surabaya - Indonesia, Email: m.luthfi@fkg.unair.ac.id

\section{INTRODUCTION}

Tooth extraction is one of the actions taken to remove a tooth from a socket. Actions of normal tooth extraction will occur a process of wound healing that is perfect, but wound healing can be done because of diabetes mellitus. Diabetes mellitus is a disease caused by chronic endocrine disorders and complications in the body either insulin deficiency, impaired sensitivity of insulin or which causes hypertension. ${ }^{1}$

According to WHO (2016), the prevalence of diabetics over the age of 18 years in 2014 is estimated globally at around 422 million patients while in Indonesia people with diabetes mellitus are estimated to continue to increase from 8.4 million sufferers in 2000 and are estimated to increase to around 21, 3 million sufferers. According to the 2015 International Diabetes Federation (IDF), people with diabetes mellitus who experience foot ulcers have grown from 9.1 million sufferers to 26.1 million sufferers worldwide. Approximately $77 \%$ of people with diabetes mellitus who experience foot ulcers recover within a period of 1 year. $^{2-4}$

The process of healing wounds such as when extracting a tooth is completed about 3 months after extraction. ${ }^{5}$ Wound healing in normal individuals involves several overlapping phases namely the inflammatory phase, the proliferation phase and the remodeling phase whereas in patients with diabetes mellitus who have a decreased immune response there is a persistent inflammatory phase and an abnormal angiogenesis process in the proliferation phase. .,7 $^{6,7}$

Vascular Endothelial Growth Factor (VEGF) is an angiogenic factor that plays an important role in the growth of new blood vessels after the occurrence of lesions that can be seen from the process of angiogenesis in the proliferation phase of wound healing. ${ }^{8,9}$ VEGF is one of the specific cytokines that are expressed when a lesion occurs in the 
body and is a vascular permeability factor that can cause increased permeability of capillaries. ${ }^{7}$

Herbal medicine is currently widely used by most people. According to WHO (2016), more than $80 \%$ of the world's population relies heavily on herbal treatments ${ }^{10,11}$ Many studies report that herbal treatments using extracts from plants have benefits in the process of wound healing. ${ }^{12,13}$ One of the herbs that can be used for wound healing is okra fruit extract because it contains flavonoid compounds. ${ }^{14}$

Flavonoids have an anti-inflammatory effect by inhibiting cyclooxygenase and lypoxygenase which play an important role in inflammation. ${ }^{15}$ Several studies have shown that okra fruit extract can also be used as an anti-diabetes. ${ }^{16}$ The state of hyperglycemia in people with diabetes mellitus can be reduced by using okra fruit because it contains isoquercetin and quercetin-3-O-beta-glucopyranosil-glucoside which is an $\alpha$-glucoside inhibitor. ${ }^{17,18}$ Barriers to the $\alpha$-glucosidase enzyme can cause polysaccharides or oligosaccharides can not be converted into monosaccharides so that glucose in the blood can decrease. Based on the above background the researchers wanted to see the effect of giving okra extract (Abelmoschus esculentus) to the increase in VEGF expression in the wound healing process.

\section{MATERIALS AND METHODS}

The study used was a laboratory experimental study with a randomized post-test only control group design approach using 24 male Wistar rats aged 2-3 months with a weight of $150 \mathrm{~g}$ each divided into two groups namely the control group (STZ induction and without okra extract) and the treatment group (STZ induction and okra fruit extract dose $250 \mathrm{mg}$ / kgBB). In a single animal, a single dose of streptozocin will be induced with a dose of $45 \mathrm{mg} / \mathrm{Dl}$ that is injected intraperitoneally until the animal is diagnosed with diabetes mellitus when the blood glucose is $\geq 200 \mathrm{mg} / \mathrm{dL}$. Blood glucose checking is carried out 3 days after STZ injection with a blood glucometer from the tail vein of the Wistar rat Wistar rat is said to have diabetes if the glucose level is $\geq$ $200 \mathrm{mg} / \mathrm{dL}^{19}$

Wistar rats that have been declared diabetic then are given anesthesia through peritoneal injection using $0.1 \mathrm{ml}$ of ketamine per rat. Wait for 1-1.5 hours from the injection, then extract the left incisors using the scalpel. Make sure that there are no leftover teeth in the tooth socket. The tooth socket is then irrigated using a saline solution. ${ }^{20-22}$ In the Control Group after extraction, it was left without okra fruit extract, while in the treatment group after the extraction was immediately given okra fruit extract at a dose of $250 \mathrm{mg} /$ $\mathrm{kg} \mathrm{BW}$ was given to the oral treatment group using gastric sonde once a day. ${ }^{23}$

Making okra extract is fresh okra fruit washed and cut into small pieces, then dried in an oven with a temperature of $50^{\circ} \mathrm{C}$ until a constant weight is reached then grown to powder. $2 \mathrm{~g}$ of dried okra powder was extracted with $20 \mathrm{ml}$ of $70 \%$ ethanol in a ratio of $1: 10(\mathrm{w} / \mathrm{v})$ during the maceration period, which is 24 hours. Extraction is carried out at room temperature with stirring at $150 \mathrm{rpm}$. After the maceration period, the mixture of the soaked powder solvent is filtered through filter paper then concentrated to $1 \mathrm{ml}$ with a rotary evaporator at $40-60^{\circ} \mathrm{C}$ and then diluted with $5 \%$ dimethyl sulfoxide (DMSO) at a ratio of 1: $1(\mathrm{v} / \mathrm{v})$. Okra fruit extracts are then stored at $-20^{\circ} \mathrm{C}$ until further use. ${ }^{24}$

Wistar rats were sacrificed on the $3 \mathrm{rd}$, 5th and 7 th day after tooth extraction by lethal injection of intraperitoneal ketamine (a minimum of 4 times the anesthetic dose or about $0.4 \mathrm{ml} / \mathrm{kg} \mathrm{BW}$ ). Then mandibular dissection was performed and fixed with $10 \%$ formalin saline for 7 days before immunohistochemical examination. ${ }^{25,26}$

The next method is to make preparations using the paraffin method and immunohistochemical painting of VEGF expression. Examination of VEGF expression on Wistar rat socket tissue preparations with diabetes mellitus was performed using a light microscope. VEGF expression will be seen as a positive immunoreactive cell by detection of brown chromogen (DAB) at the edge of the nucleus hematoxylin (HE) staining cell that is distributed on the cytoplasm or plasma membrane of the cell, whereas negative cells will correspond to the counterstain dye used. ${ }^{27}$

\section{RESULTS}

The results of the calculation of the amount of VEGF in Wistar rat tooth extraction sockets can be seen from Table 1. On the 3rd day, the average number of VEGF in the control group was 3.1563 and the treatment group was 11.8735. On the 5th day, the average number of VEGF in the control group was 8.6360 and the treatment group was 15.7397. On the 7th day, the average number of VEGF in the control group was 7.7033 and the treatment group was 16.3750. Observation results of VEGF expression with HE painting using a light microscope with $400 x$ magnification of 5 visual fields (Figure 1).

In the analysis of One-way ANOVA Post Hoc Tukey HSD test shows that there is a significant difference between the K1 group ( 3 rd day control group) compared to K2 (5th day control group), K1 (3rd day control group) compared to $\mathrm{K} 3$ (group Control day 7 ) with $\mathrm{p}<\alpha=0.05$. Results in the treatment group showed that there were significant differences between groups P1 and P2 with $\mathrm{p}<\alpha=0.05$. While in group $\mathrm{P} 1$ compared to $\mathrm{P} 2, \mathrm{P} 2$ compared to $\mathrm{P} 3$ there was no significant difference because of the value of $\mathrm{p}<\alpha=0.05$.

In the Independent T-test to find out whether there is a significant difference between the control and treatment groups that depends on the day, the results of the K1 group compared with P1, K2 compared to P2, K3 compared to P3 have significant differences because of the value of $p$ $<\alpha=0.05$.

VEGF expression will be seen as positive immunoreactive cells by detection of brown chromogen (DAB) at the edge of the hematoxylin (HE) staining cell core that is distributed on the cytoplasm or plasma cell membrane, while negative cells will correspond to the counterstain coloring agents used. ${ }^{27}$ 
Indonesian Journal of Dental Medicine Volume 2 Issue 2 2019; 35-40

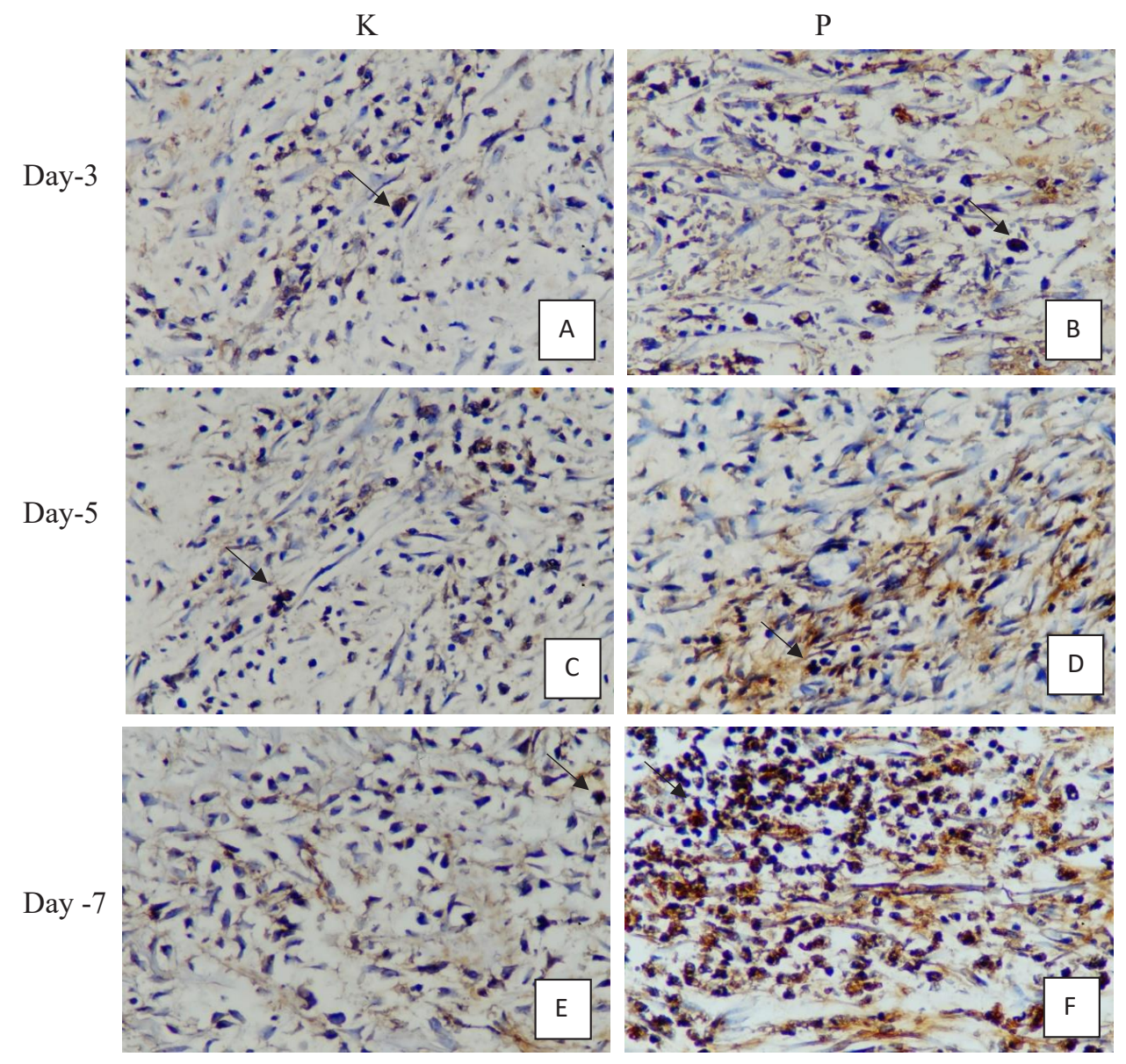

Figure 2. A. VEGF expression on the $3^{\text {rd }}$ day control group. B. VEGF expression on the $3^{\text {rd }}$ day of the treatment group. C. VEGF expression on the $5^{\text {th }}$ day of the control group. D. VEGF expression on the $5^{\text {th }}$ day of the treatment group. E. VEGF expression on the $7^{\text {th }}$ day of the control group. F. VEGF expression on $7^{\text {th }}$ day of the treatment group.

Table 1. Mean and Standard Deviation VEGF expression

\begin{tabular}{lcc}
\hline Group & Sample & Mean \pm Standard Deviation \\
\hline K1 & 4 & $3.1563 \pm 1.40451$ \\
K2 & 4 & $8.6360 \pm 1.06537$ \\
K3 & 4 & $7.7033 \pm 1.34372$ \\
P1 & 4 & $11.8735 \pm 2.25084$ \\
P2 & 4 & $15.7397 \pm 1.37211$ \\
P3 & 4 & $16.3750 \pm 2.75292$ \\
\hline
\end{tabular}

Table 2. Post Hoc Test of the Control Group

\begin{tabular}{|c|c|c|c|}
\hline Group & $\mathrm{K} 1$ & $\mathrm{~K} 2$ & $\mathrm{~K} 3$ \\
\hline $\mathrm{K} 1$ & & $0.00^{*}$ & $0.002 *$ \\
\hline $\mathrm{K} 2$ & & & 0.577 \\
\hline K3 & & & \\
\hline
\end{tabular}

Table 3. Post Hoc Test of the Treatment Group

\begin{tabular}{|c|c|c|c|}
\hline Group & P1 & $\mathrm{P} 2$ & P3 \\
\hline $\mathrm{P} 1$ & & 0.081 & $0.043 *$ \\
\hline P2 & & & 0.913 \\
\hline P3 & & & \\
\hline
\end{tabular}

Table 4. Independent T-test of the Control and Treatment Group

\begin{tabular}{lccc}
\hline Group & P1 & P2 & P3 \\
\hline K1 & $0.01^{*}$ & & \\
K2 & & $0.00^{*}$ & \\
K3 & & & $0.001^{*}$ \\
\hline
\end{tabular}


Indonesian Journal of Dental Medicine Volume 2 Issue 2 2019; 35-40

\section{DISCUSSION}

STZ injection that is carried out on experimental animals can cause selective destruction of pancreatic $\beta$ cells and cause insulin deficiency, hyperglycemia, polydipsia, polyuria which are symptoms of type I DM. STZ is able to influence blood glucose through 3 mechanisms, namely: 1) loss of insulin response, resulting in secretion of insulin is late and fails to restore prandial blood sugar spikes in normal time, 2) Decreased insulin sensitivity in response to glucose so as to cause hyperglycemia, 3) Failure to stimulate a reasonable insulin response. ${ }^{28}$ The injection given in this study as much as $45 \mathrm{mg} / \mathrm{dL}$ is a single low dose because it has a lower toxic effect compared to multiple low doses while in the administration of a single high dose STZ gives a direct toxic effect on pancreatic $\beta$ cells and can quickly cause diabetes mellitus with blood glucose $>500 \mathrm{mg} / \mathrm{dl}$ in 2 days. ${ }^{19}$

Treatment of diabetes mellitus is done by preventing the persistent inflammatory phase and increasing the wound healing process that can be done by reducing the expression of pro-inflammatory cytokines, decreasing the expression of Metallo Proteinase Matrix (MMP), stimulating angiogenesis, increasing epithelialization and increasing growth factors, one of which is VEGF. ${ }^{29}$ Efforts can be made to accelerate wound healing by increasing VEGF expression because VEGF is an important proangiogenic mediator for wound healing. Several studies have shown that increasing VEGF expression in diabetes mellitus lesions can increase lesion closure, increase granulation tissue formation and can improve the quality of wound healing. ${ }^{9}$

In the control group K1 compared to K2, K1 compared to $\mathrm{K} 3$ there was a significant difference, but in the $\mathrm{K} 2$ group compared to $\mathrm{K} 3$ there was no significant difference and a decrease in the mean VEGF expression from K2 to K3. This is comparable with the results of a study conducted by Ernawati and Sari (2018), which showed a decrease in mean VEGF expression from day 5 to day 7 in the diabetes mellitus group. ${ }^{26}$ The low expression in the control group compared to the treatment group is due to experimental animals that have been diagnosed with diabetes mellitus after injection of hyperglycemia, which causes the formation of Advanced Glycation End Products (AGEs) and when bound to the Receptor for Advanced Glycation End Products (RAGE) will increase the activation of Mitogen-Activated Protein Kinases (MAPKs), Phosphatidylinositol-3 Kinases (P13-K) and Nicotinamide Adenine Dinucleotide Phosphate Oxidase (NOX) which are the main sources of the formation of ROS..$^{30,31}$ This mechanism can lead to activation (NF) $-\mathrm{k} \beta$ which transcribes pro-inflammatory cytokines such as TNF- $\alpha$, IL-6, IL-1 $\beta .^{32}$ In diabetic Wistar rats with chronic lesions, the ability of macrophages to neutralize neutrophils is reduced so that they cannot induce shifting from M1 to M2. Increased pro-inflammatory caused by activation (NF) $-\mathrm{k} \beta$ and dysregulation of shifting M1 to M2 can cause Wistar diabetic mice to experience persistent inflammatory phase so that it becomes chronic inflammation. ${ }^{30,32}$ Thus, the VEGF expression in the control group expressed lower than in the treatment group.
The results show that there are significant differences between the control group and the treatment group. This is because the extract of okra (Abelmoschus esculentus) given to the treatment group with a dose of $250 \mathrm{mg} / \mathrm{kg} \mathrm{bb}$ contains flavonoids that act as antidiabetic, antioxidant, and anti-inflammatory properties. The content of okra extract (Abelmoschus esculentus) as an antidiabetic is isoquercetin and quercetin-3-O-beta-glucopyranosyl- (1 " $\rightarrow 6$ ") - glucoside which is an $\alpha$-glucoside inhibitor works by blocking complex glucose absorption that causes oligosaccharides and (1 " $\rightarrow 6$ ") - glucoside which is an $\alpha$-glucoside inhibitor works by blocking the absorption of glucose that causes oligosaccharides and polysaccharides cannot be converted into monosaccharides so that blood glucose levels can decrease. . $^{33,34}$

The flavonoid content as an antioxidant in okra fruit extract (Abelmoschus esculentus) has a high reactive hydroxyl group that can react with the reactive component of free radicals so that the formation of ROS can be stable and controlled which is characterized by a balance between oxidants and antioxidants. ${ }^{35,36}$ Flavonoids also act as anti-inflammatory agents through immunomodulatory mechanisms. Flavonoids can increase Th-1 and Th-2 production and IFN-production which can induce the formation of M1 and M2. M1 formed can play a role in phagocyte apoptosis from neutrophils. This is what induces shifting from phenotype M1 macrophages to M2 which results in growth factors such as VEGF. Anti-inflammatory mechanisms in flavonoids can also reduce the activity of cyclooxygenase which causes reduced prostaglandin synthesis so that the inflammation process becomes faster. ${ }^{35,37}$

The results of this study are comparable to studies conducted by Tian (2015) to test the therapeutic effect of okra extract on gestational diabetes at a dose of $200 \mathrm{mg} /$ dL showing a significant difference between the control group who did not administer okra extract and the group that administered okra extract means that a dose of 200 $\mathrm{mg} / \mathrm{dL}$ can reduce blood glucose in gestational diabetes. The dosage of $250 \mathrm{mg} / \mathrm{kg}$ bb (Abelmoschus esculentus) okra extract did not give an acute toxic effect on the liver because of the research conducted by Nurfatwa (2018) by testing okra extract (Abelmoschus esculentus) with a dose of 300,2000 and $5000 \mathrm{mg} / \mathrm{kg}$ bb shows that this dose does not cause acute toxic effects on the liver. ${ }^{38,39}$

The use of okra extract ineffective wound healing is given as therapy for 3 days after tooth extraction. That is because the results of this study showed no significant differences between treatment groups. This shows that administration with a dose of $250 \mathrm{mg} / \mathrm{kg}$ bb did not show significant differences in the treatment group given for 3 days, 5 days or 7 days.

\section{CONCLUSION}

Based on the results of this study it can be concluded that the administration of okra fruit extract (Abelmoschus 
esculentus) affects increasing the expression of VEGF on the healing process of Wistar tooth extraction wounds with diabetes mellitus.

\section{REFERENCES}

1. Ighodaro Om. Molecular Pathways Associated With Oxidative Stress In Diabetes Mellitus. Vol. 108, Biomedicine And Pharmacotherapy. Elsevier Masson Sas; 2018. P. 65662.

2. Who. Global Report On Diabetes. Isbn. 2016;978:6-86.

3. Sidartawan S, Kartini S. Hidup Secara Mandiri Dengan Diabetes Mellitus Kencing Manis Sakit Gula. Jakarta: Universitas Indonesia; 2008. 166 P.

4. International Fd. Idf Diabetes Atlas 7th Edition [Internet]. Dunia. 2015. Available From: Https://Www.Idf.Org/ELibrary/Epidemiology-Research/Diabetes-Atlas/13Diabetes-Atlas-Seventh-Edition.Html

5. Henry Cj, Stassen Lfa. The Non-Healing Extraction Socket: A Diagnostic Dilemma - Case Report And Discussion. J Ir Dent Assoc. 2016;62(4):215-20.

6. Richard Hi., Clive Cs, Allan F, Barry Gj. Textbook Of Diabetes. Fifth Edition. Singapore: Markono Printed Media; 2017.

7. Kumar P, Kumar S, Udupa Ep, Kumar U, Rao P, Honnegowda T. Role Of Angiogenesis And Angiogenic Factors In Acute And Chronic Wound Healing. Plast Aesthetic Res. 2015;2(5):243.

8. Tellechea A, Leal E, Veves A, Carvalho E. Inflammatory And Angiogenic Abnormalities In Diabetic Wound Healing: Role Of Neuropeptides And Therapeutic Perspectives !200909-05 !2009-09-20 !2010-03-04 ! Open Circ Vasc J. 2010;3(2):43-55.

9. Johnson Ke, Wilgus Ta. Vascular Endothelial Growth Factor And Angiogenesis In The Regulation Of Cutaneous Wound Repair. Adv Wound Care. 2014 Oct;3(10):647-61.

10. Ekor M. The Growing Use Of Herbal Medicines: Issues Relating To Adverse Reactions And Challenges In Monitoring Safety. Vol. 4 Jan, Frontiers In Neurology. Front Pharmacol; 2014.

11. Priya Ks, Gnanamani A, Radhakrishnan N, Babu M. Healing Potential Of Datura Alba On Burn Wounds In Albino Rats. J Ethnopharmacol. 2002 Dec 1;83(3):193-9.

12. Mirmalek Sa, Parsa T, Parsa Y, Yadollah-Damavandi S, Salimi-Tabatabaee Sa, Jangholi E, Et Al. The Wound Healing Effect Of Iris Forentina On Full Thickness Excisional Skin Wounds: A Histomorphometrical Study. Bangladesh J Pharmacol. 2016;11(1):86-90.

13. Shen Hm, Chen C, Jiang Jy, Zheng Yl, Cai Wf, Wang B, Et Al. The N-Butyl Alcohol Extract From Hibiscus Rosa-Sinensis L. Flowers Enhances Healing Potential On Rat Excisional Wounds. J Ethnopharmacol. 2017 Feb 23;198:291-301.

14. Liu S, Huang J, Li M, Zhang C, Zhu J, Zhao Y, Et Al. Study On The Flavonoids And Pectin Contents In Different Okra (Abelmoschus Escullentus L.) Accessions. J Agric Sci Bot. 2017;01(01).

15. Rathee P, Chaudhary H, Rathee S, Rathee D, Kumar V, Kohli K. Mechanism Of Action Of Flavonoids As AntiInflammatory Agents: A Review. Vol. 8, Inflammation And Allergy - Drug Targets. Bentham Science Publishers B.V.; 2009. P. 229-35.
16. Moïse Mm, Benjamin Lm, Doris Tm, Dalida Kn, Augustin No. Role Of Mediterranean Diet, Tropical Vegetables Rich In Antioxidants, And Sunlight Exposure In Blindness, Cataract And Glaucoma Among African Type 2 Diabetics. Int J Ophthalmol. 2012;5(2):231-7.

17. Vetrichelvan T, Jegadeesan M, Devi Bau. Anti-Diabetic Activity Of Alcoholic Extract Of Celosia Argentea Linn. Seeds In Rats. Biol Pharm Bull. 2002 Apr;25(4):526-8.

18. Xing $\mathrm{Xh}$, Zhang $\mathrm{Zm}, \mathrm{Hu} \mathrm{Xz}$, Wu Rq, Xu C. Antidiabetic Effects Of Artemisia Sphaerocephala Krasch. Gum, A Novel Food Additive In China, On Streptozotocin-Induced Type 2 Diabetic Rats. J Ethnopharmacol. 2009 Sep 25;125(3):410-6.

19. Furman B1. Streptozotocin-Induced Diabetic Models In Mice And Rats. Curr Protoc Pharmacol. 2015 Sep 1;70(1):5.47.15.47.20.

20. Nannochloropsis De, Terhadap O, Kepadatan P, Pada K, Mandibula O, Azmi F, Et Al. Efektifitas Perbandingan Kombinasi Clindamycin. Dent J Kedokt Gigi. 2015 Feb 1;9(1):64-73.

21. Gunawan F, S S, S S. Perbedaan Kitosan Berat Molekul Rendah Dan Tinggi Terhadap Jumlah Sel Limfosit Pada Proses Penyembuhan Luka Pencabutan Gigi. Dent J Kedokt Gigi. 2015 Feb 1;9(1):113-22.

22. Margi S. Priciple And Practice Of Veterinary Technology. St. Louis: Mosby; 2014. 120 P.

23. Shah Bn, Seth Ak. Anti-Inflammatory Activity Of Fruits Of Abelmoschus Esculantus Linn. Pharmacol . 2010;1:208-12.

24. Yeo Yl, Chia Yy, Lee Ch, Sow Hs, Yap Ws. Effectiveness Of Maceration Periods With Different Extraction Solvents On In-Vitro Antimicrobial Activity From Fruit Of Momordica Charantia L. J Appl Pharm Sci. 2014;4(10):16-23.

25. El Hady T, Karam S, El Sawa A, Saad N. Expression Of Vascular Endothelial Growth Factor During Healing Of Extraction Sockets In Diabetic Rats. Alexandria Dent J. 2015 Jul 1;40(1):120-5.

26. Ernawati Ds, Puspa A. Expression Of Vascular Endothelial Growth Factor And Matrix Metalloproteinase-9 In Apis Mellifera Lawang Propolis Extract Gel-Treated Traumatic Ulcers In Diabetic Rats. Vet World. 2018 Mar 14;11(3):304-9.

27. Sula B, Deveci E, Özevren H, Ekinci C, Elbey B. Immunohistochemical And Histopathological Changes In The Skin Of Rats After Administration Of Lead Acetate. Int J Morphol. 2016;34(3):918-22.

28. Anna Marliyati S, Roosita K. Model Tikus Diabetes Yang Diinduksi Streptozotocin-Sukrosa Untuk Pendekatan Penelitian Diabetes Melitus Gestasional Streptozotocin, Sucrose-Induce Diabetic Male Rats Model For Research Approach Of Gestational Diabetes Mellitus. Vol. 12, Jurnal Mkmi. 2016 Jun.

29. Salazar Jj, Ennis Wj, Koh Tj. Diabetes Medications: Impact On Inflammation And Wound Healing. Vol. 30, Journal Of Diabetes And Its Complications. Elsevier Inc.; 2016. P. 74652.

30. Luevano-Contreras C, Garay-Sevilla Me, ChapmanNovakofski K. Role Of Dietary Advanced Glycation End Products In Diabetes Mellitus. J Evid Based Complementary Altern Med. 2013 Jan 3;18(1):50-66.

31. Sanchez Mc, Lancel S, Boulanger E, Neviere R. Targeting Oxidative Stress And Mitochondrial Dysfunction In The Treatment Of Impaired Wound Healing: A Systematic Review. Vol. 7, Antioxidants. Mdpi Ag; 2018. 
Indonesian Journal of Dental Medicine Volume 2 Issue 2 2019; 35-40

32. Krzyszczyk P, Schloss R, Palmer A, Berthiaume F. The Role Of Macrophages In Acute And Chronic Wound Healing And Interventions To Promote Pro-Wound Healing Phenotypes. Frontiers In Physiology. Frontiers Media S.A. 2018; 9: 419.

33. Sanjay K, Jaikrit B. Alpha Glucoside Inhibitors. Type 2 Diabetes Mellitus. Edition 1st Chapter 5. Jaypee: Jaypee Publisher; 2014.

34. Thanakosai W, Phuwapraisirisan P. First Identification Of A-Glucosidase Inhibitors From Okra (Abelmoschus Esculentus) Seeds. Nat Prod Commun. 2013 Aug 1;8(8):1085-8.

35. M D, S N, Thiyagarajandevasena. Immunomodulatory And Antioxidant Actions Of Dietary Flavonoids. Int J Pharm Pharm Sci. 2014;6(2):50-6.
36. Malaysiana S, Oksidatif T, Kajian S. Oxidative StressAssociated Pathology : A Review. 2015;44(10):1441-51.

37. Landén Nx, Li D, Ståhle M. Transition From Inflammation To Proliferation: A Critical Step During Wound Healing. Vol. 73, Cellular And Molecular Life Sciences. Birkhauser Verlag Ag; 2016. P. 3861-85.

38. Tian Zh, Miao Ft, Zhang X, Wang Qh, Lei N, Guo Lc. Therapeutic Effect Of Okra Extract On Gestational Diabetes Mellitus Rats Induced By Streptozotocin. Asian Pac J Trop Med. 2015 Dec 1;8(12):1038-42.

39. Nurfatwa M. Uji Toksisitas Akut Ekstrak Buah Okra (Abelmoschus Esculatus L. Moench) Terhadap Parameter Kadar Sgot Dan Sgpt Serta Histopatologi Hepar Tikus Galur Wistar. J Pharmacopolium. 2018;1(2):88-93. 